DOI: $10.2478 / \mathrm{v} 10025-012-0012-1$

\title{
Geochemical status and interactions between soil and groundwater systems in the area of Akrefnio, Central Greece. Risk assessment, under the scope of mankind and natural environment
}

\section{Evangelos TZIRITIS, Akindinos KELEPERTSIS, Gina FAKINOU}

University of Athens, Section of Economic Geology and Geochemistry, Faculty of Geology, Panepistimioupolis, Ano Ilisia, 15784, Greece; evtziritis@geol.uoa.gr

\begin{abstract}
Totally 50 samples of groundwater and soil were collected from the area of Akrefnio (central Greece), in order to assess the geochemical status and the risk for humans and natural environment. The analytical results and processing of the initial data revealed that the main factors controlling hydrogeochemistry are the natural enrichment from calcareous substrate and the manmade pollution through extensive use of $\mathrm{N}$-fertilizers. Soil geochemistry was mainly influenced by the occurrence of lateritic horizons, which gave raise to elevated concentrations of $\mathrm{Ni}$ and $\mathrm{Cr}$ in the majority of soil samples. Although most of the geochemical enrichment processes between soil and groundwater are common, the above geochemical systems don't seem to interact, and act most of the times independently. Risk assessment of natural and mankind environment revealed that groundwater is suitable for drinking but not for irrigation, due to high salinity. Finally, soils are highly polluted by $\mathrm{Ni}$ and $\mathrm{Cr}$, and thus are inappropriate for the existing agricultural land uses.
\end{abstract}

Key words: Akrefnio, central Greece, geochemistry, groundwater, risk assessment, soil

\section{INTRODUCTION}

The study area is located in the vicinity of Akrefnio city, which lies about 100 $\mathrm{km}$ northern of Athens, central Greece. The western part of wider area is a part of a great polje which have been affected by intense karstification and tectonism. Land use has been changed over the last 100 years. More precisely, the aforementioned area was a marshy region, frequently changing between a periodic lake and a swamp. The last few years, the entire area has been drought and since then its fertile parts are under extensive agricultural practices.

The geology of the area is mainly characterized by karstic limestone formations and a thick sequence of Quaternary deposits. More precisely, the Alpine substrate consists in succession from bottom to top: Triassic dolostones and dolomitic 
limestones, a Jurassic volcanoclastic complex compiled of schists, sandstones and ultrabasic blocks, a Cretaceous sequence of pelagic limestones which hosts locally at their upper boundary Fe-Ni rich lateritic horizons and finally the typical Eocenic flysch (PAGOUNIS et al., 1994). The Post-Alpine sediments have a great thickness and embrace in succession clays, breccias, sandstones, lacustrine marls of PlioPlistocenic age, and a few lignitic intercalations. The upper sequence is consisted of Quaternary terrestrial and torrential phases with alluvial deposits (ALLEN, 1986; PAGOUNIS et al., 1994).

The existence of Fe-Ni-rich ores has been reported by several researchers in the wider area of Kopaida (ALBANTAKIS, 1984; ALBANTAKIS and KOUNDOUROS, 1984; KOUMANTAKIS, 1975; PARASKEVAIDIS, 1972). Their occurrences are found only in the northeastern extremities of the area (Aghios Ioannis) (Fig. 1) but their presence in the substrate of the area is significant due to the specific tectonic conditions (ALBANTAKIS and KOUNDOUROS, 1984).

The hydrogeological setting is mainly influenced by the specific geological and tectonic conditions. The stratigraphic contacts between formations of different permeabilities as well as the tectonic nappes and the various deformation episodes, formed three individual aquifers. The upper one is developed in the Cretaceous limestone and is characterized by high permeability and karstic flow. The middle one is developed in Jurassic limestones with elevated values of hydraulic conductivity, and the lower one is consisted of dolostones and dolomitic limestones and is differentiated from superincumbent aquifers due to the considerable decrease of permeability and karstic development. The general groundwater flow is towards east, with local differentiations. Piezometric level is variable, ranging between 20 and $160 \mathrm{~m}$ depending on local lithologic and tectonic conditions (TZIRITIS et al., 2008). The three aquifers may be considered as united in most of the cases. Discharges vary between 40 and $300 \mathrm{~km}^{3} \cdot \mathrm{h}^{-1}$, depending on the type of the aquifer. Finally, the alluvial aquifer is of minor importance and practically ignored.

The soils of the area are generally characterized by red or brownish-red colour, with heavy texture and frequent presence of breccias. They are mainly consisted of non-evoluted calciferous lacustrine sediments and therefore are classified as "Typic Haplaquent" in most of the cases, while a minor part of them is classified as "Mollic Haplaguent" (THEOCHAROPOULOS et al., 1995). The presence of root systems is frequent and the boundaries among the different horizons are abrupt and wavy. Soil structure and cohesion form satisfactory conditions concerning plant growth and biological activity.

The scope of the present paper is dual. Firstly the study aims to describe the natural and manmade processes that affect the chemistry of soils and groundwater, as well as to define the possible interaction between them. Secondly the study makes an assessment of the general environmental conditions of both soils and groundwater regarding the potential threats and the relative legislation. 


\section{METHODS}

Totally fifty samples of both groundwater (32 samples) and soil (18 samples) were collected during field work, covering an area of about $170 \mathrm{~km}^{2}$. Samples were collected during June of 2009. Regarding groundwater, samples were collected from all available boreholes of the karstic aquifer (Fig. 1).

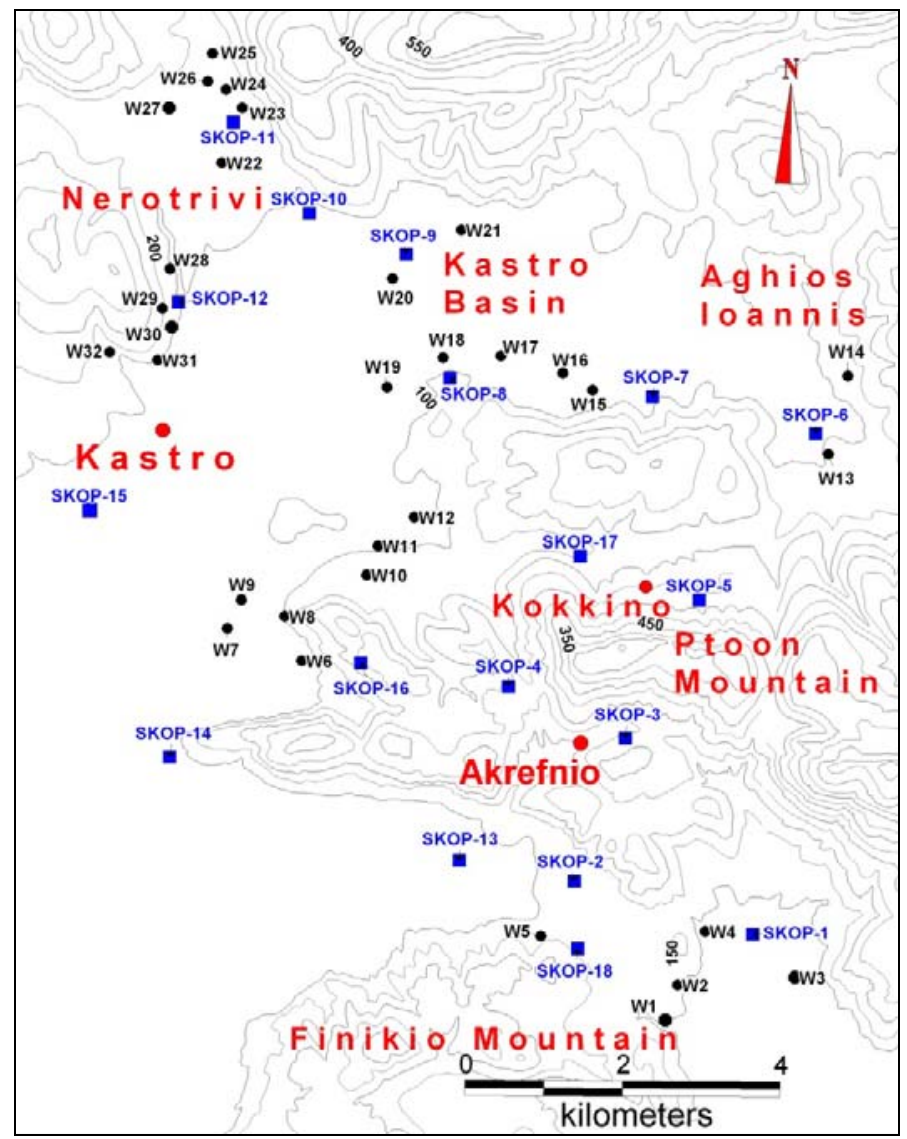

Fig. 1. Sites of groundwater (W) and soil (SKOP) samples

During sampling, all necessary precautions were taken in order to avoid any possible contamination. Totally 19 parameters were determined (Tab. 1), including major ions $\left(\mathrm{Ca}^{2+}, \mathrm{Mg}^{2+}, \mathrm{K}^{+}, \mathrm{Na}^{+}, \mathrm{Cl}^{-}, \mathrm{NO}_{3}^{-}, \mathrm{SO}_{4}{ }^{2-}\right.$ and $\mathrm{HCO}_{3}{ }^{-}$), trace elements ( $\mathrm{Al}$, $\mathrm{Ba}, \mathrm{Cr}, \mathrm{Cu}, \mathrm{Fe}, \mathrm{Mn}, \mathrm{Ni}$ and $\mathrm{Zn}$ ) and physicochemical parameters $(\mathrm{pH}, \mathrm{EC}$ and TDC) that were measured in situ. Data quality was assured by introduction of internal reference samples and by analyzing duplicates of 10 samples. The precision was calculated and found within the international standards. 
Soil samples were collected with the use of an auger sampler from a depth of $30 \mathrm{~cm}$ while surface debris and vegetation was before removed. After the proper preparation the soil samples were digested with a mixture of $\mathrm{HClO}_{4}, \mathrm{HNO}_{3}, \mathrm{HCl}$, $\mathrm{HF}$ and analyzed by an ICP-MS for the following 10 chemical parameters: $\mathrm{Al}, \mathrm{Ba}$, $\mathrm{Ca}, \mathrm{Cu}, \mathrm{Cr}, \mathrm{Fe}, \mathrm{Mg}, \mathrm{Mn}, \mathrm{Ni}$ and $\mathrm{Zn}$. Data quality was assured by introduction of internal reference samples and by analyzing the duplicates of 5 samples. The precision was calculated from these duplicates and it was found within the international standards. The results are shown in Table 3.

The initial analytical data was processed statistically in order to extract potential correlations between the parameters and assess the contribution of natural and manmade processes to the chemical status of groundwater and soils. Data have been standardized through logarithmic normalization and R-mode factor analysis was applied for both soil and groundwater samples. R-mode factor analysis is a handful method which is frequently used to similar studies (KELEPERTZIS et al., 2006; PANDA et al., 2006; TZIRITIS, 2009) and aims to specify individual factors, few in number, in order to explain the variation of a large number of variables and data. Each factor joins separate variables and finally correlates them directly or indirectly with a common process. The extraction technique for the application of factor analysis was the "principal components analysis" (DAVIS, 1984) and the results were optimized following the "Varimax rotation" method. The interpretation of each examined parameter's contribution depends on its communality, which in the case of well described parameter should be above 0.80 (ZHU et al., 2007). In other cases, where communality is below 0.80 , other processes which are not described in factor analysis might occur. The results of the R-mode factor analysis for groundwater samples are shown in Table 2 and for soils in Table 4.

A further geochemical process for the groundwater samples included the estimation of quality indices, in order to assess the quality status of the samples regarding their potential pollution or salinization. In more details, quality status was assessed through Contamination Index $\left(C_{d}\right)$ and Sodium Adsorption Ratio (SAR). The above process was followed in order to assess more thoroughly the suitability of groundwaters for human consumption and irrigation, apart from the classic procedure of comparing the analytical values with the maximum parametric levels, imposed either by the current relative legislation (Directive 98/83/EU) or the proposed international standards (FIPPS, 2003).

In more details, the quality status of an aquifer can be assessed with the use of environmental factors and indices, which include a wide spectrum of parameters. Such factors may become a valuable tool for the assessment of environmental conditions of an area. According to BACHAM et al. (1997), Contamination Index $\left(C_{d}\right)$ may be considered as a good quality environmental indicator, if we take into account the measured concentrations of the examined parameters and the upper permissible parametric levels of a contaminant. According to RAPANT et al. (1995) the Contamination Index is defined as: 


$$
C_{d}=\sum_{i=1}^{n} C_{f i} \quad \text { (1) and } C_{f i}=\frac{C_{A i}}{C_{N i}}-1
$$

where:

$C_{d}$ Contamination Index,

$C_{f i}$ contamination factor of the $i$-th component,

$C_{A i}$ analytical value of the $i$-th component,

$C_{N i}$ upper permissible concentration of the $i$-th component (defined by choice according to relative legislation or proposed international standards).

Contamination Index $\left(C_{d}\right)$ is calculated individually for each water sample, as a sum of the contamination factors of single components that exceed the maximum contaminant levels. In that way, contamination index summarizes the combinational effects of several quality parameters that may have harmful impacts to human environment. The scale value consists of three ranges (RAPANT et al., 1995), $C_{d}<1$ for low contamination, $1<C_{d}<3$ for medium contamination and $C_{d}>3$ for high contamination. It should be noted that contamination index provides only a qualitative approach to contamination and not the levels of environmental hazard, since the effects to mankind and natural environment form e.g. $\mathrm{Cr}$ and $\mathrm{Ni}$ which may be toxic are different from the effects of $\mathrm{SO}_{4}{ }^{2-}$. Results are shown on Table 3.

Furthermore, the Sodium Adsorption Ratio $(S A R)$ was calculated for each groundwater sample, in order to assess the levels of salinization and to provide a holistic approach of quality status in combination with the other data. The estimation of $S A R$ was made through the relation $S A R=\frac{N a^{+}}{\sqrt{\frac{C a^{2+}+M g^{2+}}{2}}}$

meq $\cdot 1^{-1}$ (RICHARDS, 1969) and its combination with the measured values of electrical conductivity gave information about the geochemical class of water. Results are shown on Table 3.

\section{RESULTS AND DISCUSSION}

As can be assessed from Table 1, the values of calcium in groundwater are relatively elevated, ranging from $37.8 \mathrm{mg} \cdot 1^{-1}$ to $162 \mathrm{mg} \cdot 1^{-1}$, with a mean value of $90,5 \mathrm{mg} \cdot \mathrm{l}^{-1}$, and the highest measured concentrations in samples W7 $\left(127 \mathrm{mg} \cdot \mathrm{l}^{-1}\right)$, W12 $\left(131 \mathrm{mg} \cdot \mathrm{l}^{-1}\right)$ and W13 $\left(162 \mathrm{mg} \cdot \mathrm{l}^{-1}\right)$. Magnesium ranges between $17.6 \mathrm{mg} \cdot \mathrm{l}^{-1}$ and $99.4 \mathrm{mg} \cdot 1^{-1}$ with a mean value of $43.4 \mathrm{mg} \cdot 1^{-1}$, and appear elevated values in samples W9 $\left(88 \mathrm{mg} \cdot 1^{-1}\right)$, W18 $\left(90 \mathrm{mg} \cdot 1^{-1}\right)$ and W22 $\left(99 \mathrm{mg} \cdot 1^{-1}\right)$. The ions of $\mathrm{Na}^{+}$, $\mathrm{Cl}^{-}$and $\mathrm{SO}_{4}{ }^{2-}$ appear elevated concentrations in samples $\mathrm{W} 7$, W9 and $\mathrm{W} 18$, which probably denote a common factor of enrichment. The highest values of $\mathrm{Na}^{+}$are 
found in samples W7 $\left(67 \mathrm{mg} \cdot \mathrm{l}^{-1}\right)$, W9 $\left(57 \mathrm{mg} \cdot \mathrm{l}^{-1}\right)$ and W18 $\left(83 \mathrm{mg} \cdot \mathrm{l}^{-1}\right)$, for $\mathrm{Cl}^{-}$in W7 $\left(117 \mathrm{mg} \cdot 1^{-1}\right)$, W9 $\left(86 \mathrm{mg} \cdot 1^{-1}\right)$ and W18 $\left(124 \mathrm{mg} \cdot \mathrm{l}^{-1}\right)$, and for $\mathrm{SO}_{4}{ }^{2-}$ in W7 (169 $\left.\mathrm{mg} \cdot \mathrm{l}^{-1}\right)$, W9 $\left(217 \mathrm{mg} \cdot \mathrm{l}^{-1}\right)$, W12 $\left(112 \mathrm{mg} \cdot \mathrm{l}^{-1}\right)$ and W18 $\left(256 \mathrm{mg} \cdot \mathrm{l}^{-1}\right)$. Furthermore, the concentrations of $\mathrm{K}^{+}$show a small variance and range between $1 \mathrm{mg} \cdot l^{-1}$ and 16 $\mathrm{mg} \cdot 1^{-1}$ with a mean value of $2.3 \mathrm{mg} \cdot 1^{-1}$. The highest measured values are found in samples W1 $\left(14 \mathrm{mg} \cdot 1^{-1}\right)$ and W27 $\left(16 \mathrm{mg} \cdot 1^{-1}\right)$. Nitrates appear elevated concentrations (above $40 \mathrm{mg} \cdot \mathrm{l}^{-1}$ ) in the $25 \%$ of the samples. Their concentrations range between 4 and $64.6 \mathrm{mg} \cdot 1^{-1}$, with a mean value of $25.3 \mathrm{mg} \cdot 1^{-1}$. The maximum concentrations are found in samples W5 $\left(65 \mathrm{mg} \cdot 1^{-1}\right)$, W12 (55 mg.1 $\left.{ }^{-1}\right)$ and W22 (55 $\left.\mathrm{mg} \cdot \mathrm{l}^{-1}\right)$. Finally, the concentrations of $\mathrm{HCO}_{3}$, show greater variances denoting the existence of different populations with values ranging from 205 to $451 \mathrm{mg} \cdot \cdot^{-1}$, with a mean of $297 \mathrm{mg} \cdot 1^{-1}$, and highest values in samples W22 $\left(428 \mathrm{mg} \cdot 1^{-1}\right)$ and W27 $\left(439 \mathrm{mg} \cdot \cdot^{-1}\right)$.

Table 1. Analytical results and descriptive statistics of groundwater samples; values for major elements and TDS are in $\mathrm{mg} \cdot \mathrm{l}^{-1}$, for trace elements in $\mu \mathrm{g} \cdot \mathrm{l}^{-1}$ and for $E C$ in $\mu \mathrm{S} \cdot \mathrm{cm}^{-1}$

\begin{tabular}{|c|c|c|c|c|c|c|c|c|c|c|c|}
\hline \multirow{2}{*}{$\begin{array}{c}\text { Parame- } \\
\text { ters }\end{array}$} & \multicolumn{11}{|c|}{ Major elements } \\
\hline & $\mathrm{Ca}$ & \multicolumn{2}{|c|}{$\mathrm{Mg}$} & $\mathrm{K}$ & \multicolumn{2}{|l|}{$\mathrm{Na}$} & $\mathrm{Cl}$ & $\mathrm{NO}_{3}^{-}$ & \multicolumn{2}{|c|}{$\mathrm{SO}_{4}{ }^{2-}$} & $\mathrm{HCO}_{3}$ \\
\hline Min & 37,8 & \multicolumn{2}{|c|}{17,6} & 1,0 & \multicolumn{2}{|c|}{9,0} & 12,0 & 4,0 & \multicolumn{2}{|r|}{2,0} & 205 \\
\hline Max & 162,0 & \multicolumn{2}{|c|}{99,4} & 16,4 & \multicolumn{2}{|c|}{72,9} & 123,6 & 64,6 & \multicolumn{2}{|c|}{256,0} & 451 \\
\hline Mean & 90,5 & \multicolumn{2}{|c|}{43,6} & 2,6 & \multicolumn{2}{|c|}{25,3} & 36,0 & 25,3 & \multicolumn{2}{|c|}{55,8} & 297 \\
\hline Range & 124,2 & \multicolumn{2}{|c|}{81,8} & 15,4 & \multicolumn{2}{|c|}{63,9} & 111,6 & 60,6 & \multicolumn{2}{|c|}{254,0} & 246 \\
\hline St. Dev. & 24,7 & \multicolumn{2}{|c|}{18,0} & 3,4 & \multicolumn{2}{|c|}{15,3} & 26,1 & 15,5 & \multicolumn{2}{|c|}{57,6} & 65 \\
\hline \multirow[t]{3}{*}{ Variance } & 612,3 & \multicolumn{2}{|c|}{325,3} & 11,6 & \multicolumn{2}{|c|}{234,6} & 683,2 & 241,7 & \multicolumn{2}{|c|}{3318,4} & 4262 \\
\hline & \multicolumn{11}{|c|}{ Trace elements and physicochemical parameters } \\
\hline & $\mathrm{Al}$ & $\mathrm{Ba}$ & $\mathrm{Cr}$ & $\mathrm{Cu}$ & $\mathrm{Fe}$ & $\mathrm{Mn}$ & $\mathrm{Ni}$ & $\mathrm{Zn}$ & EC & TDS & $\mathrm{pH}$ \\
\hline Min & 3 & 17 & 0 & 1 & 0 & 0 & 0 & 5 & 530 & 260 & 7,0 \\
\hline Max & 33 & 130 & 33 & 237 & 245 & 72 & 14 & 424 & 1300 & 650 & 8,3 \\
\hline Mean & 13 & 40 & 6 & 15 & 63 & 5 & 2 & 60 & 737 & 371 & 7,8 \\
\hline Range & 30 & 112 & 33 & 236 & 245 & 72 & 14 & 419 & 770 & 390 & 1,3 \\
\hline St. Dev. & 8 & 24 & 6 & 44 & 82 & 13 & 3 & 84 & 191 & 97 & 0,4 \\
\hline Variance & 69 & 555 & 37 & 1896 & 6800 & 165 & 9 & 7065 & 36467 & 9447 & 0,1 \\
\hline
\end{tabular}

Regarding the analytical values of trace elements and physicochemical parameters, all metals in general are in the range of normal values for natural waters (DREVER, 1997). A slight enrichment in some samples in comparison with the rest is observed for the parameters of $\mathrm{Ba}, \mathrm{Cu}, \mathrm{Cr}, \mathrm{Ni}, \mathrm{Mn}$ and $\mathrm{Zn}$. More precisely, elevated values of $\mathrm{Ba}$ are found in samples W6 $\left(89 \mu \mathrm{g} \cdot 1^{-1}\right)$ and W7 $\left(130 \mu \mathrm{g} \cdot 1^{-1}\right)$ while the mean value is $40 \mathrm{mg} \cdot \mathrm{l}^{-1}$. Elevated values for $\mathrm{Cu}$ are found in samples W3 (237 $\left.\mu \mathrm{g} \cdot \mathrm{l}^{-1}\right)$, W27 $\left(99 \mu \mathrm{g} \cdot \mathrm{l}^{-1}\right)$ and W30 $\left(39 \mu \mathrm{g} \cdot \mathrm{l}^{-1}\right)$, while the mean value is $15 \mu \mathrm{g} \cdot \mathrm{l}^{-1}$. Furthermore, Cr appear elevated values in samples W13 $\left(13 \mu \mathrm{g} \cdot \mathrm{l}^{-1}\right)$ and W22 $\left(33 \mu \mathrm{g} \cdot \mathrm{l}^{-1}\right)$ while mean value is $6 \mu \mathrm{g} \cdot 1^{-1}$, Ni in sample W24 $\left(14 \mu \mathrm{g} \cdot \mathrm{l}^{-1}\right)$ while mean value is 
$2 \mu \mathrm{g} \cdot \mathrm{l}^{-1}$, Mn in sample W7 $\left(72 \mu \mathrm{g} \cdot \mathrm{l}^{-1}\right)$ while mean value is $5 \mu \mathrm{g} \cdot 1^{-1}$, and $\mathrm{Zn}$ in samples W10 $\left(221 \mu \mathrm{g} \cdot 1^{-1}\right)$, W13 $\left(424 \mu \mathrm{g} \cdot 1^{-1}\right)$ and W18 $\left(210 \mu \mathrm{g} \cdot 1^{-1}\right)$ while the mean value is $60 \mu \mathrm{g} \cdot 1^{-1}$. Finally, the values of $E C$ and TDS present great variance, denoting the impact from different factors, while $\mathrm{pH}$ is slightly alcalic, reaching values up to 8.3 .

The application of R-mode factor analysis in groundwater samples resulted to the existence of five factors (Tab. 2) that control $77.1 \%$ of the hydrogeochemical status. Depending on their communalities, only the parameters TDS, $E C, \mathrm{Na}^{+}$, $\mathrm{SO}_{4}{ }^{2-}, \mathrm{Mg}^{2+}, \mathrm{Cl}^{-}, \mathrm{Ba}^{2+}, \mathrm{Cr}, \mathrm{pH}, \mathrm{Ca}^{2+}, \mathrm{Al}$ and $\mathrm{NO}_{3}{ }^{-}$appear values equal or greater than 0,80 and can be well interpreted.

Table 2. Sorted Rotated Factor Loadings and Communalities for groundwater samples, values below 0.4 are presented as zero for simplification

\begin{tabular}{l|c|c|c|c|c|c}
\hline \multicolumn{1}{c}{ Variable } & Factor 1 & Factor 2 & Factor 3 & Factor 4 & Factor 5 & Communality \\
\hline $\mathrm{TDS}$ & 0.967 & 0.000 & 0.000 & 0.000 & 0.000 & 0.950 \\
$\mathrm{EC}$ & 0.962 & 0.000 & 0.000 & 0.000 & 0.000 & 0.941 \\
$\mathrm{Na}$ & 0.897 & 0.000 & 0.000 & 0.000 & 0.000 & 0.856 \\
$\mathrm{SO}_{4}$ & 0.835 & 0.000 & 0.000 & 0.000 & 0.000 & 0.844 \\
$\mathrm{Mg}$ & 0.790 & 0.000 & 0.000 & 0.000 & 0.000 & 0.886 \\
$\mathrm{Cl}$ & 0.770 & 0.000 & 0.000 & 0.000 & 0.000 & 0.897 \\
$\mathrm{Ba}$ & 0.730 & -0.491 & 0.000 & 0.000 & 0.000 & 0.837 \\
$\mathrm{HCO}$ & 0.551 & 0.529 & 0.000 & 0.000 & 0.000 & 0.622 \\
$\mathrm{Mn}$ & 0.512 & 0.000 & 0.000 & -0.452 & 0.000 & 0.559 \\
$\mathrm{Ni}$ & 0.467 & 0.000 & 0.441 & 0.000 & 0.000 & 0.676 \\
$\mathrm{~K}$ & 0.405 & 0.000 & 0.000 & 0.000 & 0.000 & 0.565 \\
$\mathrm{Cr}$ & 0.000 & 0.872 & 0.000 & 0.000 & 0.000 & 0.860 \\
$\mathrm{pH}$ & 0.000 & 0.849 & 0.000 & 0.000 & 0.000 & 0.874 \\
$\mathrm{Zn}$ & 0.000 & 0.579 & 0.000 & 0.000 & 0.000 & 0.639 \\
$\mathrm{Ca}$ & 0.000 & 0.000 & 0.882 & 0.000 & 0.000 & 0.824 \\
$\mathrm{Al}$ & 0.000 & 0.000 & 0.000 & -0.813 & 0.000 & 0.795 \\
$\mathrm{Cu}$ & 0.000 & 0.000 & 0.000 & -0.716 & 0.000 & 0.576 \\
$\mathrm{NO}{ }_{3}$ & 0.000 & 0.000 & 0.000 & 0.000 & 0.930 & 0.899 \\
$\mathrm{Fe}$ & 0.000 & 0.000 & 0.439 & 0.000 & -0.513 & 0.553 \\
$\mathrm{Variance}$ & 6.1680 & 2.9590 & 1.9813 & 1.9134 & 1.6312 & 14.6530 \\
$\%$ Var & 0.325 & 0.156 & 0.104 & 0.101 & 0.086 & 0.771 \\
\hline
\end{tabular}

The first factor explains $32.5 \%$ of the chemical variance and includes with high positive factor loadings the parameters of TDS, $E C, \mathrm{Na}^{+}, \mathrm{SO}_{4}{ }^{2-}, \mathrm{Mg}^{2+}, \mathrm{Cl}^{-}$, with medium positive factor loadings the parameters of $\mathrm{Ba}^{2+}, \mathrm{HCO}_{3}^{-}, \mathrm{Mn}$, and with weak positive loadings the parameters $\mathrm{Ni}$ and $\mathrm{K}^{+}$. This factor includes saline water related parameters which may have an origin from different sources, such as seawater intrusion or dissolution of evaporitic minerals. 
The second factor explains $15.6 \%$ of chemical variance and includes with high positive factor loadings the parameters of $\mathrm{Cr}$ and $\mathrm{pH}$, with medium positive factor loading the parameters of $\mathrm{Zn}$ and $\mathrm{HCO}_{3}^{-}$, and with weak negative loading $\mathrm{Ba}^{2+}$. A possible interpretation of this factor would be the impact of the lateritic horizons which are Cr-rich and the contribution of $\mathrm{pH}$ as regulatory parameter controlling solubility and mobility of the aqueous solution.

The third factor explains $10.4 \%$ of the chemical variance and includes with high positive factor loading $\mathrm{Ca}^{2+}$, and with weak positive loadings the parameters $\mathrm{Ni}$ and $\mathrm{Fe}$, and possible interprets the influence of the calcareous substrate through the process of karstification. The negative values of factor loadings of $\mathrm{Ni}$ and $\mathrm{Fe}$ probably denote the lithological differences and the local spatial dominance of the ultrabasic blocks of the volcanoclastic formation where limestones are absent.

The fourth factor explains $10.1 \%$ of the chemical variance and includes with high negative factor loading $\mathrm{Al}$, with medium negative loading $\mathrm{Cu}$ and with weak negative loading $\mathrm{Mn}$, and probably interprets the contribution from the ultrabasic blocks of the volcanoclastic formation.

Finally, the fifth and last factor explains $8.6 \%$ of the total chemical variance and includes with high positive factor loading the parameter of $\mathrm{NO}_{3}^{-}$and with medium negative loading the parameter of $\mathrm{Fe}$. The possible interpretation of this factor should be attributed to the impact of mankind pollution, through the extensive use of fertilizers. The negative value of Fe probably refers to local reducing conditions (TZIRITIS, 2009), where $\mathrm{NO}_{3}^{-}$and $\mathrm{Fe}^{3+}$ are depleted because of reduction, and the aqueous solution is enriched in $\mathrm{N}$ and $\mathrm{Fe}^{2+}$.

As can be assessed from Table 3 the majority of groundwater samples belong to $\mathrm{Ca}-\mathrm{HCO}_{3}$ water type denoting the significant influence of the calcareous substrate, and only few of them to $\mathrm{Mg}-\mathrm{HCO}_{3}$ type due to the impact of ultrabasic formations and dolomitic aquifer. It is quite noticeable that although the contamination index of the groundwater samples is rather low, salinity which is expressed through the values of SAR is elevated in many of them. This assessment is due to the fact that contamination index embraces parameters that are harmful to human environment as they are imposed by the relative legislation, while $S A R$ and salinity hazard refers to the irrigation quality of groundwater, thus takes into account the natural environment. The elevated values of $S A R$ should be attributed to local elevated values of $\mathrm{Na}^{+}$which might be related with several origins of salinization, such as seawater intrusion, dissolution of evaporitic minerals, connate water etc.

Comparing the analytical results with the parametric values of the 98/83/EU Directive, it can be concluded that only in 5 samples the maximum acceptable limits are exceeded. In more details, the maximum concentration of $\mathrm{NO}_{3}^{-}\left(50 \mathrm{mg} \cdot \mathrm{l}^{-1}\right)$ is exceeded only in samples W5, W8 and W22, while the maximum concentrations of $\mathrm{SO}_{4}{ }^{2-}\left(250 \mathrm{mg} \cdot 1^{-1}\right)$ and $\mathrm{Mn}\left(50 \mu \mathrm{g} \cdot \mathrm{l}^{-1}\right)$ are exceeded only in samples W18 and W7 respectively. Regarding the parametric values of heavy metals and metalloids 
Table 3. Summary table depicting water type for groundwater samples, ionic ratios of $\mathrm{Mg}: \mathrm{Ca}, \mathrm{SAR}$ values, the relative salinity hazard, as well as Contamination Index $\left(C_{d}\right)$ and levels of contamination

\begin{tabular}{|c|c|c|c|c|c|c|c|}
\hline & Water type & $\begin{array}{c}\mathrm{Mg}: \mathrm{Ca} \\
\text { meq }\end{array}$ & SAR & $\begin{array}{l}\text { Salinity } \\
\text { Hazard }\end{array}$ & $\mathrm{Cd}$ & Cfi & Contamination \\
\hline W1 & $\mathrm{Ca}-\mathrm{HCO}_{3}$ & 0.614 & $385 \times 10^{-3}$ & medium & 0 & - & none \\
\hline W2 & $\mathrm{Ca}-\mathrm{HCO}_{3}$ & 0.837 & $904 \times 10^{-3}$ & medium & 0 & - & none \\
\hline W3 & $\mathrm{Ca}-\mathrm{HCO}_{3}$ & 0.747 & $101 \times 10^{-3}$ & medium & 0 & - & none \\
\hline W4 & $\mathrm{Ca}-\mathrm{HCO}_{3}$ & 0.557 & $805 \times 10^{-3}$ & medium & 0 & - & none \\
\hline W5 & $\mathrm{Ca}-\mathrm{HCO}_{3}$ & 0.718 & $467 \times 10^{-3}$ & medium & 0.3 & $\mathrm{NO}_{3}^{-}$ & low \\
\hline W6 & $\mathrm{Ca}-\mathrm{HCO}_{3}$ & 0.616 & $523 \times 10^{-3}$ & high & 0 & - & none \\
\hline W7 & $\mathrm{Ca}-\mathrm{HCO}_{3}$ & 0.830 & 1.21 & medium & 0.4 & $\mathrm{Mn}$ & low \\
\hline W8 & $\mathrm{Ca}-\mathrm{HCO}_{3}$ & 0.867 & $965 \times 10^{-3}$ & medium & 0 & $\mathrm{NO}_{3}^{-}$ & none \\
\hline W9 & $\mathrm{Mg}-\mathrm{HCO}_{3}$ & 1.330 & $983 \times 10^{-3}$ & high & 0 & - & none \\
\hline W10 & $\mathrm{Ca}-\mathrm{HCO}_{3}$ & 0.704 & $550 \times 10^{-3}$ & medium & 0 & - & none \\
\hline W11 & $\mathrm{Ca}-\mathrm{HCO}_{3}$ & 0.705 & $480 \times 10^{-3}$ & medium & 0 & - & none \\
\hline W12 & $\mathrm{Ca}-\mathrm{HCO}_{3}$ & 0.494 & $374 \times 10^{-3}$ & high & 0.1 & - & low \\
\hline W13 & $\mathrm{Ca}-\mathrm{HCO}_{3}$ & 0.241 & $271 \times 10^{-3}$ & medium & 0 & - & none \\
\hline W14 & $\mathrm{Ca}-\mathrm{HCO}_{3}$ & 0.685 & $328 \times 10^{-3}$ & medium & 0 & - & none \\
\hline W15 & $\mathrm{Ca}-\mathrm{HCO}_{3}$ & 0.784 & $365 \times 10^{-3}$ & medium & 0 & - & none \\
\hline W16 & $\mathrm{Ca}-\mathrm{HCO}_{3}$ & 0.697 & $329 \times 10^{-3}$ & medium & 0 & - & none \\
\hline W17 & $\mathrm{Ca}-\mathrm{HCO}_{3}$ & 0.748 & $338 \times 10^{-3}$ & medium & 0 & - & none \\
\hline W18 & $\mathrm{Mg}-\mathrm{HCO}_{3}$ & 1.559 & 1.29 & high & 0.1 & $\mathrm{SO}_{4}^{2-}$ & low \\
\hline W19 & $\mathrm{Ca}-\mathrm{HCO}_{3}$ & 0.891 & $520 \times 10^{-3}$ & medium & 0 & - & none \\
\hline W20 & $\mathrm{Ca}-\mathrm{HCO}_{3}$ & 0.937 & $421 \times 10^{-3}$ & high & 0 & - & none \\
\hline W21 & $\mathrm{Mg}-\mathrm{HCO}_{3}$ & 1.075 & $414 \times 10^{-3}$ & medium & 0 & - & none \\
\hline W22 & $\mathrm{Mg}-\mathrm{HCO}_{3}$ & 4.335 & $737 \times 10^{-3}$ & high & 0.1 & $\mathrm{NO}_{3}^{-}$ & low \\
\hline W23 & $\mathrm{Ca}-\mathrm{HCO}_{3}$ & 0.773 & $251 \times 10^{-3}$ & medium & 0 & - & none \\
\hline W24 & $\mathrm{Ca}-\mathrm{HCO}_{3}$ & 0.816 & $635 \times 10^{-3}$ & medium & 0 & - & none \\
\hline W25 & $\mathrm{Ca}-\mathrm{HCO}_{3}$ & 0.881 & $625 \times 10^{-3}$ & high & 0 & - & none \\
\hline W26 & $\mathrm{Mg}-\mathrm{HCO}_{3}$ & 1.225 & $336 \times 10^{-3}$ & medium & 0 & - & none \\
\hline W27 & $\mathrm{Ca}-\mathrm{HCO}_{3}$ & 0.682 & $373 \times 10^{-3}$ & medium & 0 & - & none \\
\hline W28 & $\mathrm{Ca}-\mathrm{HCO}_{3}$ & 0.706 & $400 \times 10^{-3}$ & medium & 0 & - & none \\
\hline W29 & $\mathrm{Ca}-\mathrm{HCO}_{3}$ & 0.689 & $375 \times 10^{-3}$ & medium & 0 & - & none \\
\hline W30 & $\mathrm{Ca}-\mathrm{HCO}_{3}$ & 0.746 & $121 \times 10^{-3}$ & high & 0 & - & none \\
\hline W31 & $\mathrm{Ca}-\mathrm{HCO}_{3}$ & 0.920 & $560 \times 10^{-3}$ & high & 0 & - & none \\
\hline W32 & $\mathrm{Ca}-\mathrm{HCO}_{3}$ & 0.624 & $225 \times 10^{-3}$ & medium & 0 & - & none \\
\hline
\end{tabular}

for long and short term exposure of vegetation (FIPPS, 2003), it should be concluded that none of the samples exceeds the maximum imposed values. 
SOILS

From Table 4 it shown that the concentrations of calcium in soils range between 0.6 and $31 \%$ w.w., with a mean value of $11 \%$ w.w., and the highest values in samples S7, S8, S9, S15 and S16. Magnesium ranges between 0.4 and 8.1\% w.w. with a mean of $1.4 \%$ w.w., and the highest values in samples S2 $(3.3 \%$ w.w.) and S12 (8.1\% w.w.). The concentrations of Nickel appear to be elevated, ranging between 36 and $1569 \mathrm{mg} \cdot \mathrm{kg}^{-1}$, with a mean value of $472 \mathrm{mg} \cdot \mathrm{kg}^{-1}$. The highest values are found in samples S3 $\left(876 \mathrm{mg} \cdot \mathrm{kg}^{-1}\right)$, S5 (1569 $\left.\mathrm{mg} \cdot \mathrm{kg}^{-1}\right), \mathrm{S} 6\left(976 \mathrm{mg} \cdot \mathrm{kg}^{-1}\right), \mathrm{S} 10$ $\left(857 \mathrm{mg} \cdot \mathrm{kg}^{-1}\right)$ and S12 $\left(1160 \mathrm{mg} \cdot \mathrm{kg}^{-1}\right)$. The values of $\mathrm{Cr}$ range between 19 and 921 $\mathrm{mg} \cdot \mathrm{kg}^{-1}$ with a mean of $241 \mathrm{mg} \cdot \mathrm{kg}^{-1}$, and the highest values are found in samples S5 $\left(591 \mathrm{mg} \cdot \mathrm{kg}^{-1}\right)$ and $\mathrm{S} 6\left(921 \mathrm{mg} \cdot \mathrm{kg}^{-1}\right)$. The concentrations of $\mathrm{Al}$ range between 0.2 and $2.8 \%$ w.w. with a mean value of $1.5 \%$ w.w. and the highest concentrations in samples S3 $(2.78 \%$ w.w.) and S11 $(2.76 \%$ w.w.). Furthermore, the highest concentrations compared to other samples for $\mathrm{Zn}$ are found in samples S3 (124 $\mathrm{mg} \cdot \mathrm{kg}^{-1}$ ) and S5 (98 $\left.\mathrm{mg} \cdot \mathrm{kg}^{-1}\right)$, for Mn in samples S3 $\left(1295 \mathrm{mg} \cdot \mathrm{kg}^{-1}\right)$ and S11 $\left(1113 \mathrm{mg} \cdot \mathrm{kg}^{-1}\right)$, for $\mathrm{Fe}$ in samples S3 (5.3\% w.w.), S5 (6.9\% w.w.) and S6 (6.2\% w.w.), for $\mathrm{Cu}$ in samples S3 (41 mg. $\left.\mathrm{kg}^{-1}\right)$ and $\mathrm{S} 6\left(41 \mathrm{mg} \cdot \mathrm{kg}^{-1}\right)$, and finally for Ba in samples S1 $\left(147 \mathrm{mg} \cdot \mathrm{kg}^{-1}\right)$ and S11 $\left(145 \mathrm{mg} \cdot \mathrm{kg}^{-1}\right)$.

Table 4. Analytical results and descriptive statistics of soil samples; values are on $\mathrm{mg} \cdot \mathrm{kg}^{-1}$ except of $\mathrm{Ca}, \mathrm{Mg}, \mathrm{Al}$ and $\mathrm{Fe}$ where are on \% w.w.

\begin{tabular}{lrlllr|r|r|r|r|r|r}
\hline Parameters & \multicolumn{1}{c|}{$\mathrm{Ca}$} & $\mathrm{Mg}$ & $\mathrm{Al}$ & $\mathrm{Cu}$ & \multicolumn{1}{c}{$\mathrm{Zn}$} & \multicolumn{1}{c}{$\mathrm{Ni}$} & \multicolumn{1}{c}{$\mathrm{Mn}$} & $\mathrm{Fe}$ & \multicolumn{1}{c}{$\mathrm{Cr}$} & $\mathrm{Ba}$ \\
\hline Min & 0.6 & 0.4 & 0.2 & 6 & 20 & 36 & 185 & 0.3 & 19 & 39 \\
Max & 31.0 & 8.1 & 2.8 & 41 & 124 & 1569 & 1295 & 6.9 & 921 & 147 \\
Mean & 11.0 & 1.4 & 1.5 & 22 & 60 & 472 & 585 & 2.9 & 241 & 95 \\
Range & 30.3 & 7.7 & 2.6 & 35 & 104 & 1533 & 1110 & 6.7 & 902 & 108 \\
St. Dev. & 10.3 & 1.8 & 0.7 & 11 & 27 & 447 & 299 & 1.9 & 242 & 30 \\
Variance & 106.7 & 3.3 & 0.5 & 114 & 739 & 200079 & 89148 & 3.6 & 58403 & 910 \\
\hline
\end{tabular}

According to Table 5 which depicts the extracted factors of the applied R-mode factor analysis, the chemical variation of soils is interpreted through three factors that explain the $88.7 \%$ of the total variance. The communalities for the examined parameters exceed the value of 0.80 , thus all parameters are well described. The first factor explains $54.7 \%$ of total variance and includes with high positive factor loadings the parameters of $\mathrm{Ni}, \mathrm{Cr}, \mathrm{Fe}, \mathrm{Mn}, \mathrm{Zn}, \mathrm{Al}$ and with medium ones the parameters of $\mathrm{Cu}$ and $\mathrm{Mg}$. The interpenetration of this factor should be related with the lateritic horizons of the area as well as with the ultrabasic blocks of the volcanoclastic formation. The second factor explains $18 \%$ of total variance and includes with high positive factor loading $\mathrm{Ca}$, while $\mathrm{Al}$ and $\mathrm{Cu}$ appear antithetic negative medium loadings. This factor probably interprets the influence of the calcare- 
Table 5. Sorted Rotated Factor Loadings and Communalities for soils; values below 0.4 are presented as zero for simplification

\begin{tabular}{l|c|c|c|c}
\hline \multicolumn{1}{c|}{ Variable } & Factor 1 & Factor 2 & Factor 3 & Communality \\
\hline $\mathrm{Ni}$ & 0.954 & 0.000 & 0.000 & 0.959 \\
$\mathrm{Cr}$ & 0.944 & 0.000 & 0.000 & 0.932 \\
$\mathrm{Fe}$ & 0.906 & 0.000 & 0.000 & 0.958 \\
$\mathrm{Mn}$ & 0.869 & 0.000 & 0.000 & 0.805 \\
$\mathrm{Zn}$ & 0.817 & 0.000 & 0.000 & 0.882 \\
$\mathrm{Al}$ & 0.752 & -0.501 & 0.000 & 0.834 \\
$\mathrm{Cu}$ & 0.693 & -0.567 & 0.000 & 0.824 \\
$\mathrm{Ca}$ & 0.000 & 0.933 & 0.000 & 0.919 \\
$\mathrm{Ba}$ & 0.000 & 0.000 & -0.933 & 0.919 \\
$\mathrm{Mg}$ & 0.542 & 0.000 & 0.716 & 0.835 \\
Variance & 5.4689 & 1.8026 & 1.5959 & 8.8675 \\
$\%$ Var & 0.547 & 0.180 & 0.160 & 0.887 \\
\hline
\end{tabular}

ous substrate. Finally, the third factor which explains the $16 \%$ of total variance includes with high negative loading $\mathrm{Ba}$ and with antithetic medium positive loading $\mathrm{Mg}$, probably interpreting the influence from Triassic dolostones.

Regarding groundwater, the prevailing calcareous substrate is the main factor that characterizes the hydrogeochemical conditions. Totally 26 out 32 samples appear calcium values greater than $75 \mathrm{mg} \cdot \mathrm{l}^{-1}$, a threshold that defines the impact of calcareous basins (APPELO and POSTMA, 2005). Elevated values of calcium are accompanied in most of the cases with elevated values of $\mathrm{HCO}_{3}{ }^{-}$confirming the existence of karstification process which is expressed through the reaction $\mathrm{CaCO}_{3}+\mathrm{H}_{2} \mathrm{O}+\mathrm{CO}_{2} \rightarrow \mathrm{Ca}^{2+}+2 \mathrm{HCO}_{3}^{-}$and is significant in the area due to the large number of karstic caves and katavothraes. In a few cases, the simultaneous elevated values of calcium and magnesium (e.g. W7, W9 and W18) denote the impact of the Triassic dolostone, which is hosted in the substrate. The elevated values of calcium are not spatially related, but insignificantly scattered, probably related more with underground topography of the substrate rather than the geological formations over the surface. When calcium values are low and magnesium on the contrary elevated (compared with the rest of the samples) the influence of the ultrabasic blocks of the volcanoclastic formation is significant in hydrogeochemistry, mainly through the dissolution of Mg-rich silicate minerals, such as olivine, amphibole and pyroxene.

An interesting assessment is made through the estimation of ionic ratios of $\mathrm{Mg}: \mathrm{Ca}$ (Tab. 3), which reveals that in 13 (42\%) of the samples the ratio is ranging between 0.5 and 0.7 denoting impact of calcareous formations (Jurassic and Cretaceous limestones), 12 (37\%) of the samples range between 0.7 and 0.9 denoting impact of dolostones, and 7 (21\%) of the samples have values above 0.9 denoting impact of ultrabasic formations. The percentage of dolomitic impact is not relative 
with the analytical values, as well as with the water types since $\mathrm{Mg}-\mathrm{HCO}_{3}$ type is found only in 5 samples, thus leading to the conclusion that the scattered existence of ultrabasic blocks has given a rise to the total concentration of magnesium, resulting to groundwater samples whose ionic ratios of $\mathrm{Mg}: \mathrm{Ca}$ are similar with those of dolomitic impact. The above fact was confirmed by field works, where the outcropping dolostones had minor spatial existence, and from the hydrogeological conditions which impose that the Triassic dolomitic aquifer is not extended due to statigraphic and tectonic factors.

Nevertheless, the weathering of limestones and generally the karstification phenomena seems to be the main factor that controls the geochemistry of soils. In total 7 out of 18 samples appear elevated values of calcium (13.4 to 31\%) but the compare with the neighbouring groundwater samples reveals that (apart from samples W13-S6) there is no significant spatial correlation between the elevated values of $\mathrm{Ca}$ in soils and those in groundwater. The same happens for magnesium, as there is no correlation between the $\mathrm{Mg}$ elevated values in soils and groundwater. This should be attributed to the fact that the main enrichment source of $\mathrm{Mg}$ are the ultrabasic formations of the substrate which rarely have surface occurrences in the area, thus the weathering that mainly affects the geochemistry of soils has limited impact on the upper horizons. On the contrary, the existence of volcanoclastic formations in various depths affect frequent the hydrogeochemistry of groundwater.

The presence of $\mathrm{Ni}$ and $\mathrm{Cr}$ in groundwater samples is less than expected, according to the presence of lateritic horizons in the lithological sequence of the area and the concentrations of the aforementioned metals in soil samples. In more details, nickel in groundwater is present in minor concentrations, ranging from $6 \mathrm{ppb}$ to $14 \mathrm{ppb}$, only in few samples (W3, W11, W12, W13 and W24), while chromium appears slightly elevated concentrations (ranging from $12 \mathrm{ppb}$ to $33 \mathrm{ppb}$ ) compared with nickel in samples W2, W13, W14, W22 and W28. Despite the fact that Cr and Ni possible have the same origin (lateritic horizons and ultrabasic rocks) they don't appear similar elevations in their concentrations of groundwater samples, apart from sample W13. In all other cases the fluctuation of their concentrations is different, probably denoting regulation from external factors. A more thorough assessment of the analysis reveals that the elevated values of $\mathrm{Cr}$ related with $\mathrm{pH}$ values ranging from 8.1 to 8.4 and relatively the elevated values of $\mathrm{Ni}$ are related with $\mathrm{pH}$ values ranging from 7 to 7.8 , denoting a possible influence, a fact which is in accordance with the results of the second factor of R-mode analysis (Tab. 2) which includes $\mathrm{pH}$ and $\mathrm{Cr}$ with high positive factor loadings. In addition, the differences in mobility of $\mathrm{Cr}$ and $\mathrm{Ni}$ and subsequently in the variation of their concentrations in aqueous solutions might be attributed to other geochemical phenomena. In more details, a significant increase in the mobility of $\mathrm{Ni}$ might occur when nickel is associated with carbonates (BINOTTO et al., 2000), a fact which is confirmed by the chemical analyses and the third factor of R-mode analysis. 
On the contrary, Ni appears high concentrations in soils, which should be attributed to the impact of the Ni-rich lateritic horizons that occur at the geological substrate of the area. The elevated values of $\mathrm{Ni}$ in soils are accompanied in most of the cases with elevated values of $\mathrm{Fe}, \mathrm{Cr}, \mathrm{Al}$ and $\mathrm{Mn}$, which exist in the weathering crusts of laterite in the wider area (SKARPELIS, 2006). Only in few cases (northern of Kastro and southern of Aghios Ioannis) the elevated values of $\mathrm{Ni}$ and $\mathrm{Cr}$ are related with an increase in the concentrations of $\mathrm{Ni}$ and $\mathrm{Cr}$ in groundwater. In all other cases soil and groundwater geochemistry are not related, regarding the values of $\mathrm{Cr}$ and $\mathrm{Ni}$.

The assessment of the statistical processing of initial data, revealed the impact of a single factor to hydrogeochemistry that was not clearly indicated directly through chemical analysis. As we can assess by the first factor of R-mode analysis, there is an elevation in some samples in the values of TDS, $E C, \mathrm{Na}^{+}, \mathrm{SO}_{4}{ }^{2-}, \mathrm{Mg}^{2+}$ and $\mathrm{Cl}^{-}$, which probably denotes a common source of enrichment. All the aforementioned parameters are seawater related (HEM 1985), so a scenario that would adopt a potential seawater intrusion in the eastern parts of the study area might interpret this phenomenon. But the hydrogeological evidences (PAGOUNIS et al., 1994) show that there is not such a case for the area, leading to the conclusion that the increased salinity may be attributed to another factor. Since the enrichment from airborne sea-spray should be excluded due to the local climatic conditions (general annual wind direction) and topography (the study area is surrounded by mountains), the salinization should attributed to the paleo-environmental conditions of the area.

In more details, the study area was a part of the former Lake of Kopais, which periodically had frequent changes in water level accompanied by high temperatures (ALLEN, 1984). The above fact played a major role for the formation of evaporitic fluoresences in the limestone outcrops that were revealed after the periodic decrease of water level (TZIRITIS, 2008). Similar fluoresences are frequently present with the form of crusts in Lakes with high organic content and specific climatic conditions (high temperature and evapotranspiration) with the form of trona $\left(\mathrm{Na}_{2} \mathrm{CO}_{2} \cdot \mathrm{NaHCO}_{3} \cdot 2 \mathrm{H}_{2} \mathrm{O}\right)$, tenardite $\left(\mathrm{Na}_{2} \mathrm{SO}_{4}\right)$ and halite $(\mathrm{NaCl})$, over organic debris or fine bedded sandy depositions (TSIPOURA and STAMATAKIS, 2004; 2005). All the above conditions resemble with the paleo-environment of the area, resulting to the fact that the salinization source of enrichment should be attributed to evaporitic crusts. This scenario is also confirmed, apart from the hydrogeological evidences, by two more important notes. If salinization were related with seawater intrusion, apart from the elevated values of the aforementioned seawater related parameters, the concentrations of $\mathrm{K}^{+}$should be also elevated. This fact is not valid, so the origin of $\mathrm{Na}^{+}, \mathrm{SO}_{4}{ }^{2-}$ and $\mathrm{Cl}^{-}$should be different, for example dissolution of tenardite or halite. Moreover, if seawater intrusion had occurred that would mean a more widespread spatial distribution of salinization, and not a local one, such as in our case which occurs only for samples neighbouring with limestone outcrops. 
An interesting note is made for $\mathrm{Ba}^{2+}$ which appears elevated concentrations (related to other samples) in some of the groundwater samples (W6, W7, W8 and $\mathrm{W} 18$ ) ranging from 70 to $130 \mathrm{ppb}$. These samples (except W18) are spatially related concluding to the fact of a common source of enrichment. This source should be possibly attributed to the dissolution of barite $\left(\mathrm{BaSO}_{4}\right)$, as the highest values of sulphates appear also in these samples. The occurrence of barite, although it was not detected by mineralogical methods, it is quite possible to exist since barite can be formed in organic rich calcareous sediments through diagenetic processes (STAMATAKIS and HeIN, 2004). On the contrary, $\mathrm{Ba}^{2+}$ concentrations in soils are low and even those samples which appear slightly elevated values compared with the others, do not appear any spatial correlation with the elevated values in groundwater samples. This might be interpreted by the existence of a secondary source of enrichment which is major for soil geochemistry, such as the content of the volcanoclastic formations in $\mathrm{Ba}^{2+}$.

The elevated values of copper in groundwater samples W3, W27 and W30 (237 ppb, $99 \mathrm{ppb}$ and $39 \mathrm{ppb}$ respectively) are not associated with any other parameter. In fact, all other parameters in these samples appear decreased values compared with other samples, except W30 which appear elevated value for nitrates (44 ppm). This fact may interpret the elevated values of $\mathrm{Cu}$ which might be related with nitrate fertilizers and/or pesticides which are used intensively in the area. In other case, secondary geochemical processes might occur (e.g. complexation) which increases the mobility and concentrations of copper, while the rest heavy metals (e.g. $\mathrm{Cr}, \mathrm{Ni}, \mathrm{Zn}, \mathrm{Fe}$ ) which are related either with the volcanoclastic formations or the lateritic horizons are low. On the contrary, copper is correlated in the geochemistry of soils samples with $\mathrm{Zn}, \mathrm{Mn}, \mathrm{Fe}$ and $\mathrm{Ni}$, since their highest values co-exist in the same samples, probably denoting the impact from a weak sulfide mineralization.

Finally, an important factor which influences the chemical status of groundwater is the manmade pollution, which derives from the extensive use of $\mathrm{N}$-fertilizers. Totally 8 samples (W5, W12, W20, W21, W22, W25, W30 and W31) out of 18 appear elevated concentrations ranging from $40 \mathrm{ppm}$ to $65 \mathrm{ppm}$. The spatial distribution of the above samples denote that there is not an extended contaminated plume, but local contaminated areas which are probably due to specific enrichment conditions related with infiltration and magnitude of enrichment (use of fertilizers). It is quite noticeable that in samples with elevated $\mathrm{NO}_{3}{ }^{-}$values the concentrations of $\mathrm{Fe}$ are low, while in the samples with the highest $\mathrm{Fe}$ concentrations nitrates are abnormally decreased. The above fact, which is confirmed also by the fifth factor of R-mode analysis, interprets the local reducing conditions which are developed in some areas (TZIRITIS, 2009), where $\mathrm{NO}_{3}{ }^{-}$and $\mathrm{Fe}^{3+}$ are depleted because of reduction, and the aqueous solution is enriched in $\mathrm{N}$ and $\mathrm{Fe}^{2+}$.

The risk assessment for the quality status of groundwater and soils, regarding the impact to biota and fauna, resulted to the following. Groundwater is in general 
suitable for drinking, as no extended contamination phenomena were detected. The contamination index is negligible for the majority of the samples, and only five of them appear minor contamination conditions, regarding the parametric values imposed by the relative legislation (Directive 98/83/EU). In more details, the main pollutant of groundwater are nitrates which appear elevated concentrations (above $40 \mathrm{mg} \cdot 1^{-1}$ ) in the $25 \%$ of the samples, while three of them (W5, W12 and W22) appear concentrations which exceed the proposed levels of $50 \mathrm{mg} \cdot 1^{-1}$ for use as potable water (Directive 98/83/EU). In addition, $\mathrm{Mn}$ and $\mathrm{SO}_{4}{ }^{2-}$ exceed the maximum parametric values of the relative Directive in samples W7 (72 ppb) and W18 (256 $\mathrm{ppm})$ respectively. On the contrary, the salinity conditions of the samples as were assessed by the values of $S A R$, denote that most of the samples are not suitable for irrigation, especially for plants which are sensitive to high salinization. The content of heavy metals in groundwater has no impact to plants either for short or long term exposure, except the value of $\mathrm{Cu}$ in $\mathrm{W} 3$ for long-term exposure (Tab. 6).

Table 6. Maximum parametric levels for irrigation waters regarding long and short term use (FIPPS, 2003)

\begin{tabular}{c|c|c}
\hline Constituent & Long-term use, $\mathrm{mg} \cdot \mathrm{l}^{-1}$ & Short-term use $\mathrm{mg} \cdot \mathrm{l}^{-1}$ \\
\hline $\mathrm{Al}$ & 5.0 & 20 \\
$\mathrm{Cr}$ & 0.1 & 1 \\
$\mathrm{Cu}$ & 0.2 & 5 \\
$\mathrm{Fe}$ & 5.0 & 20 \\
$\mathrm{Mn}$ & 0.2 & 10 \\
$\mathrm{Ni}$ & 0.2 & 2 \\
$\mathrm{Zn}$ & 2.0 & 10 \\
\hline
\end{tabular}

Regarding soils, as can be extracted from Table 7, the concentrations of $\mathrm{Ba}$, $\mathrm{Cu}$, and $\mathrm{Zn}$ are below the parametric values of both Canadian and Dutch limits. Serious environmental problems derive form the concentrations of $\mathrm{Ni}$, which exceed the maximum imposed parametric values of both Canadian and Dutch standards in many soil samples. In more details, the Canadian limit for Ni is exceeded in 11 samples, while the Dutch in 10 samples. The above fact raises a significant environmental pressure regarding Nickel concentrations in soils, and poses the fact that most of the soils covering the area are inappropriate for specific uses, such as agricultural land. It should be noted that the majority of the area is used for agricultural purpose, such as the cultivation of green vegetables which are intended for human consumption. The maximum concentrations for $\mathrm{Cr}$ are exceeded in two of the samples regarding the Canadian limits, and in 5 samples regarding the Dutch ones which have lower values. 
Table 7. Canadian and Dutch maximum parametric values for soils concerning the examined parameters of the soil samples

\begin{tabular}{c|c|c}
\hline Parameter & $\begin{array}{c}\text { Canadian limits, } \mathrm{mg} \cdot \mathrm{kg}^{-1} \\
\text { agricultural land }\end{array}$ & $\begin{array}{c}\text { Dutch limits, } \mathrm{mg} \cdot \mathrm{kg}^{-1} \\
\text { soils (general) }- \text { urgent action }\end{array}$ \\
\hline $\mathrm{Ba}$ & 750 & 625 \\
$\mathrm{Cr}$ & 750 & 380 \\
$\mathrm{Cu}$ & 150 & 190 \\
$\mathrm{Ni}$ & 150 & 210 \\
$\mathrm{Zn}$ & 600 & 720 \\
\hline
\end{tabular}

Source: Canadian Soil Quality Guidelines for the Protection of Environmental Human and Health; The new Dutch list.

\section{CONCLUSIONS}

The analytical data as well as the geochemical and statistical processing revealed that hydrogeochemical status of groundwater is influenced mainly by the extensive use of fertilizers, which impose elevated values of nitrate. Additionally, the paleo-environmental conditions gave rise to the formation of evaporitic crusts, which define locally the chemical status of groundwater through their dissolution. Other natural factors that control hydrogeochemistry are the calcareous substrate and lateritic horizons.

Soil geochemistry is majorly influenced by the geological formations of the area, and more specifically by the volcanoclastic formations as well as from the limestones.

The common impact of the above factors to soil and groundwater chemical status was observed only in very few cases. That means that these two geochemical systems act independently and don't seem to be related.

The risk assessment of both soil and groundwater samples revealed that there is no significant environmental threat regarding groundwater, a fact which differentiates for soils as the elevated values of $\mathrm{Ni}$ and $\mathrm{Cr}$ in most of the samples pose a serious environmental problem.

\section{REFERENCES}

1. Appelo C., Postma D., 2005. Geochemistry, groundwater and pollution. $2^{\text {nd }}$ ed. A.A. Balkema Publishers, The Netherlands.

2. Albantakis N., Koundouros D., 1984. Nickel minerals of the Eastern Greece geotectonical unit. Mineral Wealth, 31: 22-37.

3. Albantakis N., 1984. Discover and trace of Fe-Ni-rich ores in Kopaida with the use of geomagnetic methods and boreholes. Mineral Wealth, 31: 12-25.

4. Allen H.D., 1984. Late Quaternary of the Kopais Basin, Greece: Sedimentary and environmental history. PhD Thesis, University of Cambridge: 1-172. 
5. Backman B., Bodis D., Lahermo P., RAPAnt S., TARVAinen T., 1998. Application of a groundwater contamination index in Finland and Slovakia. Journal of Environmental Geology, 36, 1-2: 5564.

6. Binotto R.D., Texeira E.C., Sanchez J.C.D., Migliavacca D., Nanni A.S., 2000. Environmental assessment: contamination of phreatic aquifer in areas impacted by wastes from coal processing activities. Fuel, 79: 1547-1560.

7. Davis J., 1984. Statistics and data analysis in geology. $2^{\text {nd }}$ ed. New York, Wiley: 1-646.

8. FIPPS G., 2003. Irrigation water quality standards and salinity management. Texas Cooperative Extension, Texas A\&M University, B-1667, 4-03: 1-19.

9. Hem J., 1985. Study and interpretation of the chemical characteristics of natural water. U.S. Geological Survey, Water Supply Paper, 2254: 1-264.

10. Kelepertsis A., AleXakis D., Skordas K., 2006. Arsenic, antimony and other toxic elements in the drinking water of Eastern Thessaly in Greece and its possible effects on human health. Environmental Geology, 50: 76-84.

11. Koumantakis I., 1975. New evidences about the Fe-Ni-rich ores of Yliki. Ann. Geol. Des Pays Hell., 17: 34-55.

12. Pagounis M., Gkertzos T., Gkatzoyiannis A., 1994. Hydrogeological study of Viotikos Kifisos basin. Technical report, I.G.M.E (in Greek).

13. Panda U.C., Sundaray S.K., Rath P., Nayak B., Bhatta D., 2006. Application of factor and cluster analysis for characterization of river and estuarine water systems - A case study: Mahanadi River (India). Journal of Hydrology, 331: 434-445.

14. PARASKEVAIDIS I., 1972. The geology of the area Lakes Yliki and Paralimni: Review of former and recent evidences. (in Greek). Technical Chronicles, 3: 11-27.

15. RAPANT S., VRANA K., BodiS D., 1995. Geochemical atlas of Slovak Republic. P. 1. Bratislava, Groundwater, Geofond.

16. RICHARDS L., 1969. Diagnosis and improvement of saline and alkali soils. USA Salinity Laboratory Staff. Agriculture Handbook, 60: 1-631.

17. SKARPELIS N., 2006. Lateralization processes of ultramafic rocks in Cretaceous times: The fossil weathering crusts of mainland Greece. Journal of Geochemical Exploration, 88: 325-328.

18. Stamatakis M., Hein J.R., 1993. Origin of barite in Tertiary marine sedimentary rocks from Lefkas Island, Greece. Economic Geology, 88: 91-103.

19. Theocharopoulos S., Karagianni M., Christou P., Gkatzogianni P., Afentaki A., Aggelidis S., 1995. Diachronic notes in inorganic nitrogen concentrations in the cultivated regions of Kopaida soils and waters. Geotechnical Scientific Issues, 6, 4.

20. TSiPOURA-Vlachou M., StAMATAKIS M., 2005 Mineralogy and geochemistry of evaporitic clay formations of the alkaline lake pikrolimni, Macedonia, Greece. $7^{\text {th }}$ Hellenic Hydrogeological Conference, Athens, 2: 319-334.

21. Tsipoura-Vlachou M., Stamatakis M., 2004. On the occurrence of trona and thenardite in Pikrolimni Lake, central Macedonia, Greece. $5^{\text {th }}$ International Symposium on Eastern Meditterenean Geology, Thessaloniki, Greece, 14-20 April 2004.

22. TZIRITIS E., 2009. Groundwater and soil geochemistry of Eastern Kopaida region (Beotia, central Greece). Central European Journal of Geosciences, 1, 2: 219-226.

23. TZiritis E., KelepertZis A., Stamatakis M.G., 2008. Hydrogeochemical and environmental conditions of East Kopaida-Yliki karst groundwater system. $8^{\text {th }}$ International Hydrogeological Congress, Athens, Greece, 2: 733-742.

24. ZHU G.F., Li Z.Z., SU Y.H., Ma J.Z., ZHANG Y.Y., 2007. Hydrogeochemical and isotope evidence of groundwater and recharge in Minqin Basin, Northwest China. Journal of Hydrology, 333: 239251. 


\section{STRESZCZENIE}

Stan geochemiczny i oddziaływania między glebą a systemem wód podziemnych na obszarze Akrefnio, środkowa Grecja. Ocena zagrożeń dla ludzi i środowiska naturalnego

Słowa kluczowe: Akrefnio, geochemia, gleba, ocena ryzyka, środkowa Grecja, woda gruntowa

Pobrano 50 próbek gleby i wody gruntowej z obszaru Akrefnio (środkowa Grecja) do oceny stanu geochemicznego i zagrożeń ludzi i środowiska naturalnego. Wyniki analiz i przetworzenie danych ujawniły, że głównymi czynnikami hydrogeochemicznymi są zasilanie $\mathrm{z}$ wapiennego podłoża i antropogeniczne zanieczyszczenia, pochodzące z nadmiernego stosowania nawozów azotowych. Geochemia gleby podlegała silnym wpływom laterytowych poziomów, które zwiększały stężenie niklu i chromu w większości próbek glebowych. Choć większość procesów geochemicznych między glebą a wodami gruntowymi ma charakter powszechny, opisany system nie wykazywał interakcji, a jego elementy funkcjonowały w większości niezależnie. Ocena zagrożeń naturalnego środowiska wykazała, że woda gruntowa nadaje się do spożycia, ale nie do nawodnień z powodu silnego zasolenia. Gleby są w wysokim stopniu zanieczyszczone niklem i chromem, dlatego są nieodpowiednie do obecnego wykorzystania rolniczego. 